\title{
METAMERIC LIGHT SOURCES: A RECENT PARADIGM FOR FUNCTIONAL LIGHTING
}

\author{
Andrius Petrulis ${ }^{1, \#}$, Pranciškus Vitta ${ }^{1}$, Justina Aglinskaitè ${ }^{1}$, Rimantas Vaicekauskas ${ }^{2}$, \\ and Artūras Žukauskas ${ }^{1}$ \\ ${ }^{1}$ Institute of Applied Research, Vilnius University, Saulètekio Ave. 3, Vilnius, LT-10222, LITHUANIA \\ ${ }^{2}$ Department of Computer Science, Vilnius University, Didlaukio St. 47, LT-08303 Vilnius, LITHUANIA \\ \# Corresponding author: andrius.petrulis@tmi.vu.It
}

Communicated by Ivars Lācis

\begin{abstract}
Recent progress in tuneable solid-state light sources opens new opportunities in a niche and high added value lighting applications. The standard colorimetric technique of composing an identical colour coordinate metameric light spectra are facing the challenges due to the colour discrepancy noticed by the observers. A side-by-side colour matching experiment was performed with two tuneable tetrachromatic RAGB lamps (638 nm red, $598 \mathrm{~nm}$ pc amber, $518 \mathrm{~nm}$ green, $451 \mathrm{~nm}$ blue LEDs) to compare the colour of the metameres in a 10-deg viewing angle. The metameric light matching was investigated using a 2-deg (CIE 1931) and 10-deg (CIE 1964) XYZ colour matching function. Both colour matching functions of standard colorimetric observers were shown to be inaccurate for aligning of metameric spectral power distributions without a noticeable difference in a perceived colour. On the other hand, a wide scatter of individual results revealed that the standard colour matching functions are inherently limited and in some cases, especially in professional lighting applications, the individually adjustable metameric lighting approach is to be considered.
\end{abstract}

Key words: colour quality, tuneable solid-state light, photometry, metamerism.

\section{INTRODUCTION}

Recent progress of solid-state lighting (SSL) technology based on light-emitting diodes (LEDs) opens new opportunities in energy saving, sustainability and increased added value by implementing smart, multifunctional lighting (Almeida et al., 2014). The phenomenon of the light having different spectral power distributions (SPDs) to be perceived as the same colour is called metamerism and can be employed to advantage as easy as never before. Novel tuneable SPD light sources have been shown to be applicable for illumination of artwork (Tuzikas et al., 2014), retail scenes (Barati et al., 2015) and for controlling of human circadian (Gall, 2002; Lang, 2011) rhythms as well as other niche needs. On the other hand, metameric light sources may influence the perceived colours of illuminated objects; therefore, colour quality of metameres should be taken into account. Recently, several new colour rendition metrics, based on the product of illumination and reflectance spectra have been introduced (Anonymous, 1995; Rea and Freyssinier-Nova, 2008; Žukauskas et al., 2009; Davis and Ohno, 2010) and continuously enhanced (David et al.,
2015 ) in order to quantify the colour rendition ability of the artificial light-sources.

The principle of colour perception relies on a human's chromatic response inside the fovea and brain perception. In order to quantify the colour perception, the simple colour model called Standard Colorimetric Observer was introduced by Commission Internationale de l'Éclairage (CIE) in 1931 (Anonymous, 2006) for the 2-deg field of view, updated in 1964 (Anonymous, 2007) for the 10-deg and later attempts, in order to make this model as accurate as possible (Hu et al., 2005; Anonymous, 2006). It is considered that $95 \%$ of humans' colour vision (with exclusion of colour-blindness) is accurately represented by this model (Wyszecki and Styles, 1982), but still there are numbers of visual characteristics not included in this simplification. Age, gender, fatigue, colour-blindness, diseases, chromatic adaptation, background colour, surface luminance etc. can be significant factors for deviation from the Standard Colorimetric Observer model. For example, it was found that individuals exhibit an observer metamerism with different Colour Matching Functions (CMFs) which is important 
even for industrial applications and assessment of colour rendering (Sarkar et al., 2010). Despite the already known discrepancy of the CIE1931 2-deg XYZ CMFs (Wyszecki and Styles, 1982), most lighting professionals and scientists employ 2-deg CMFs and related photometric, colorimetric methods. Regardless of new 2-deg and 10-deg CMFs introduced in 2006 (Anonymous, 2006), the old ones are widely used. Furthermore, a similar situation occurs with the definition of undistinguishing colour differences (ellipses) (MacAdam, 1942; Brown, 1957; Wyszecki and Fielder, 1971), as the earlier introduced and highly criticised MacAdam ellipses (MacAdam, 1942) are currently the most widely used. Earlier experiments with metameric light sources have shown that those sources are perceived as mismatched colours (Houser and Hu, 2004; Vidovszky-Nemeth and Schanda, 2012; Royer and Houser, 2012) and 2-deg or 10-deg CMFs (Anonymous, 2007) were addressed to be responsible for the perceived significant colour differences. The lack of sufficiently accurate CMFs for practical applications slightly discredits the metameric light sources approach of the modern multifunction tuneable SPD lighting.

In the current study we aimed to experimentally demonstrate the discrepancy of CIE 1932 2-deg and CIE 1964 10deg photometry for the modern narrow band solid-state metameric light source (Žukauskas et al., 2012), using 10deg field of view side-by-side metameric colour matching.

\section{MATERIALS AND METHODS}

In order to clarify the subjective colour match perception of metameric light sources, two psychophysical experiments of side-by-side comparison and colour matching were carried out. The experimental booth was made from black matted PVC board with $10 \mathrm{~cm} \times 10 \mathrm{~cm}$ interior dimensions for visual area (Fig. 1) and illuminated at 300 lx. The view field was divided into two halves using the same black material. A round Spectralon ${ }^{\circledR} 32 \mathrm{~mm}$ white target was mounted in the centre and illuminated by two independently adjustable lamps. The observation distance was maintained at approx.

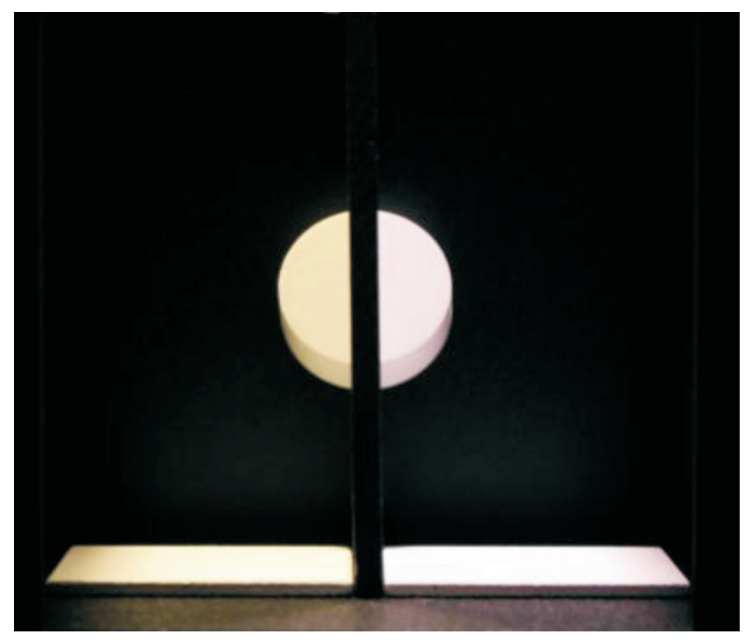

Fig. 1. View field of the experimental setup. $10 \times 10 \mathrm{~cm}$ box separated with black sheet in the middle. Top mounted independently adjustable tetrachromatic lamps illuminate the same object.
$18 \mathrm{~cm}$ in order to obey 10-deg viewing angle conditions. Such a viewing angle was selected in order to represent a more realistic situation when subjects perceive the information from a broader angle. The head or eye movement of the subjects was not limited in any direction and the experiment was performed in a totally dark room with no external light except experimental ones. Tetrachromatic RAGB (638 nm red, $598 \mathrm{~nm}$ pc amber, $518 \mathrm{~nm}$ green, $451 \mathrm{~nm}$ blue) LED clusters were used with adjustable Correlated Colour Temperature (CCT) and AGB-RGB weight parameter $\sigma$ (sigma) (Žukauskas et al., 2012). The SPDs of the light sources at $3000 \mathrm{~K}$ and different $\sigma$ values are depicted in Figure 2, while CCT was calculated and colour coordinates selected using CIE 1964 10-deg CMFs. The calibration of the LED light sources was performed with an Illumia Pro® system and on-site illumination was double checked with an Avantes AvaSpec-ULS2048x64TEC spectrometer. A software for the experimental procedure and data acquisition was developed for the Windows ${ }^{\circledR}$ operating system with the USB game pad as a user interface and control unit. Subjects were asked to press ergonomically positioned arrows ("left", "right", "up" and "down") and "OK" in order to change the illumination parameters and to confirm the best colour match selection, respectively.

The first experiment was carried out to match the perceived colour of two lamps having the same CCT (3000 K) e.g., colour coordinates $(0.4860 ; 0.4106)$ according to CIE 1931 10-deg observer CMF, but with different spectral weight parameters $\sigma$. One lamp was fixed at $\sigma$ values $0,0.5$ or 1 , while another had a randomly selected value of sigma from 0 to 1 in step of 0.1 . The subjects were allowed to tune the second lamp along the isotemperature line of $3000 \mathrm{~K}$ only, and the corresponding shift from Planckian locus $\mathrm{D}_{\mathrm{uv}}$ (Wyszecki and Stiles, 1982) was recorded (red vertical line in Fig. 3). Two verbally instructed subjects (male - 28 years and female -21 years) with a normal colour vision participated in this experiment. In order to assess and compensate the biases of the spectral sensitivity difference of

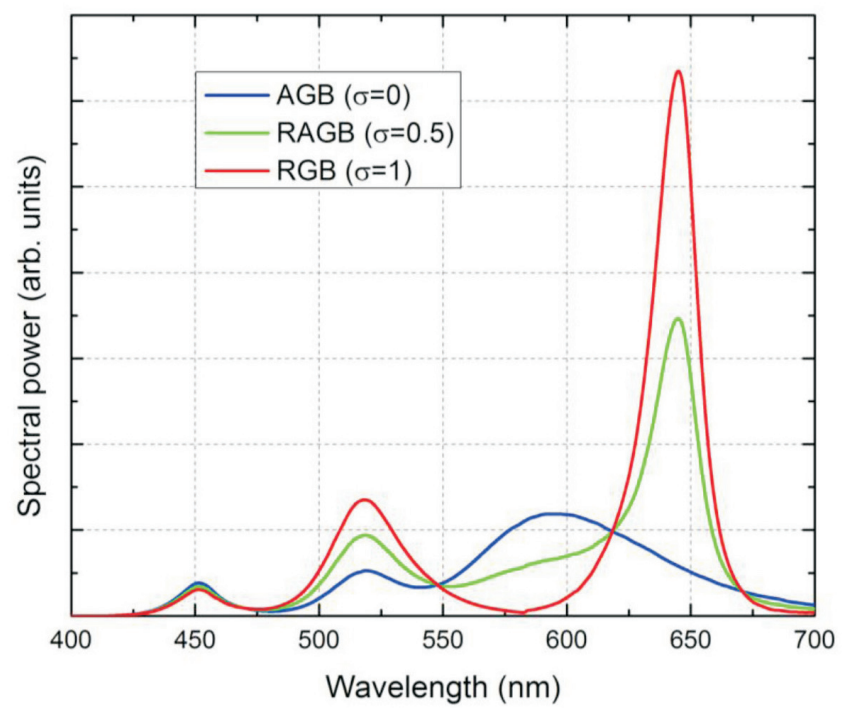

Fig. 2. Spectral power distributions of the metameric RAGB sources aligned at $3000 \mathrm{~K}$ colour point accordingly to the 10-deg CMFs. 


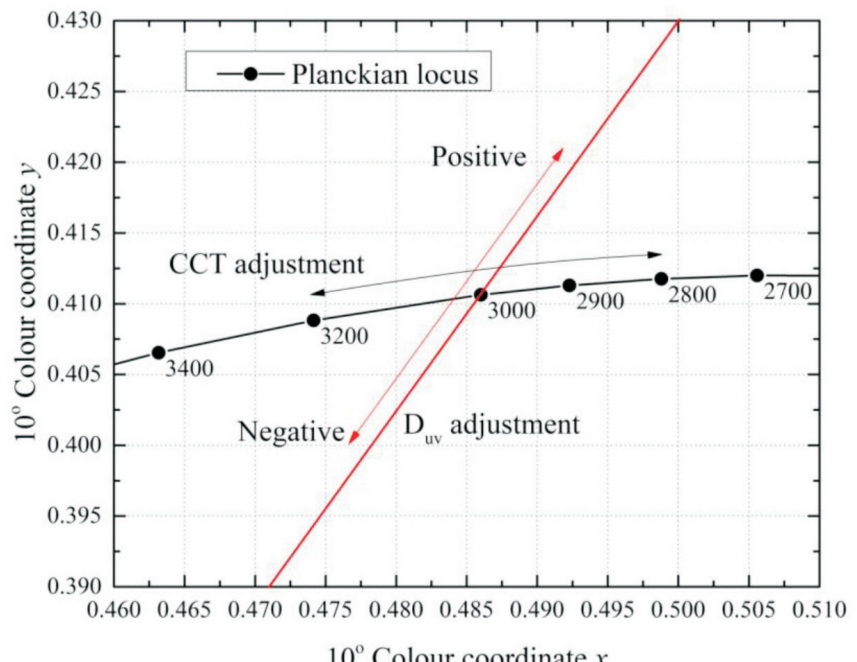

$10^{\circ}$ Colour coordinate $x$

Fig. 3. Experimental lamp adjustment diagram with ability to control $\mathrm{D}_{\mathrm{uv}}$ and CCT independently.

the eyes, adjustable cabinet position and SPD calibration, the experiments were performed with single eye vision (right and left separately while the other was closed with an eye-patch) and repeated with lamps swapped. By changing the experimented and closed eye, the eye bias was identified to $\mathrm{D}_{\mathrm{uv}}=0.0002$ and $\mathrm{D}_{\mathrm{uv}}=-0.001$ for subjects No 1 . and No. 2, respectively, and were subtracted from the experimental results. In particular, the left eye of participant No 1 needed a greater greenish component while the left eye of No 2 needed a more purplish spectral component. The origin of the eye bias probably could be addressed to anatomical difference of the eyes. Adjustable cabinet position bias was traced by swapping the lamps and keeping the same lighting parameters. It was found that position bias was 0.003 , which probably corresponds to the different perceived brightness (Houser et al., 2003; Rea et al., 2011) of left and right cabinets. SPD bias was eliminated by comparing results from both adjustable cabinet positions at the same lighting setup with $\sigma$ values of $0,0.5$ and 1 . It was reported that one luminaire was a bit too reddish and correction to green was made $\left(\mathrm{D}_{\mathrm{uv}}=0.0003\right)$. The minimal $\mathrm{D}_{\mathrm{uv}}$ step was 0.0008 and set by software with a distance less than one MacAdam ellipse (0.0025) along the isothermal line. Therefore, each subject performed 72 matching attempts in experimental sessions that were shorter than 30 min. in order to maintain fatigue.

The second experiment was performed in a similar way to the first one where subjects were allowed to adjust one of the lamps in 2D space by changing the CCT in addition to $\mathrm{D}_{\mathrm{uv}}$ (Fig. 3). In contrast to the several sigma values used in the first experiment, here the lamps were set to purely RGB $(\sigma=1$, right side) and AGB $(\sigma=0$, left side) spectral compositions and only AGB cluster parameters (CCT and $\mathrm{D}_{\mathrm{uv}}$ ) were adjusted. Twenty subjects with normal or corrected to normal vision (13 males and 7 females with average age of the 28 years) participated in this experiment and they were instructed in the same way as in the first experiment, with 5 min adaptation time and the following trial attempt. The

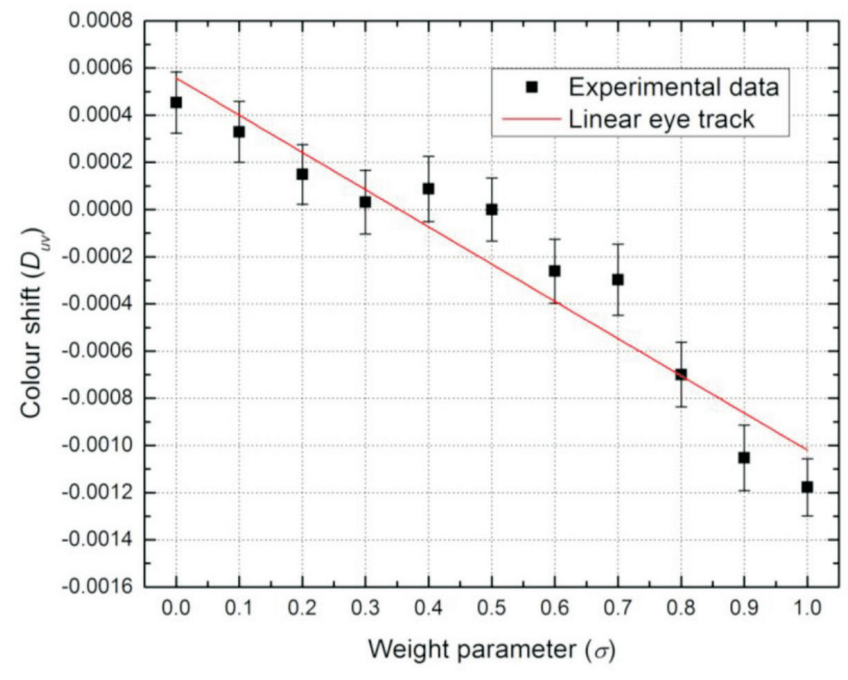

Fig. 4. Colour matching results of metameric (10-deg colour space) RAGB light sources of different AGB-RGB weight parameters $(\sigma)$ with central position of RAGB $(\sigma=0.5)$ by changing $\mathrm{D}_{\mathrm{uv}}$. Linear trend provided for the eye track.

fixed RGB light source was set to approximately $3000 \mathrm{~K}$ at 2-deg CMFs. The initial parameters (starting points) of adjustable AGB source were randomly selected by software around the $3000 \mathrm{~K}$ RGB point. Eye and lamps biases in this experiment were neglected, based on the data obtained from the first experiment, and binocular vision was used.

\section{RESULTS}

The results of the first experiment are depicted in Figure 4. Solid points represent the obtained average of the selected $\mathrm{D}_{\mathrm{uv}}$ for each sigma value in comparison to the reference lamp SPD $(\sigma=0.5)$. All reference lamp settings (for $\sigma$ values of $0,0.5$ or 1 ) and bias values were included in the resulting average of relative $\mathrm{D}_{\mathrm{uv}}$ shifts. The linear trend is depicted only for the eye track, since there is no scientific evidence for the linear dependence. One can notice in Fig. 3 that AGB dominating metameric SPDs $(\sigma<0.5)$ were set to have positive $\mathrm{D}_{\mathrm{uv}}$, which means that they appeared too purplish for the subjects and were compensated by raising the $\mathrm{D}_{\mathrm{uv}}$. The RGB dominating metameric SPDs $(\sigma>0.5)$ were perceived in an opposite way - too greenish and were shifted below the Planckian locus. On the other hand, regardless of the $\mathrm{D}_{\mathrm{uv}}$ adjustment, subjects were not satisfied with the colour matching results, indicating that control of single $\mathrm{D}_{\mathrm{uv}}$ is not sufficient. Therefore, the second experiment with $2 \mathrm{D}$ control was introduced.

The results of the second experiment are depicted in Figures 5 and 6 . Each solid circle shows the selected colour coordinates of the AGB light source matching the colour of RGB for the single subject in the experiment. The results are depicted in 2-deg and 10-deg colour spaces in Figures 5 and 6, respectively. The 3-step MacAdam ellipse in Figure 5 illustrates the scale of data scattering and was calculated using the geodesic method (MacAdam, 1971). One can notice that selected points are somehow closer to the theoretical value 


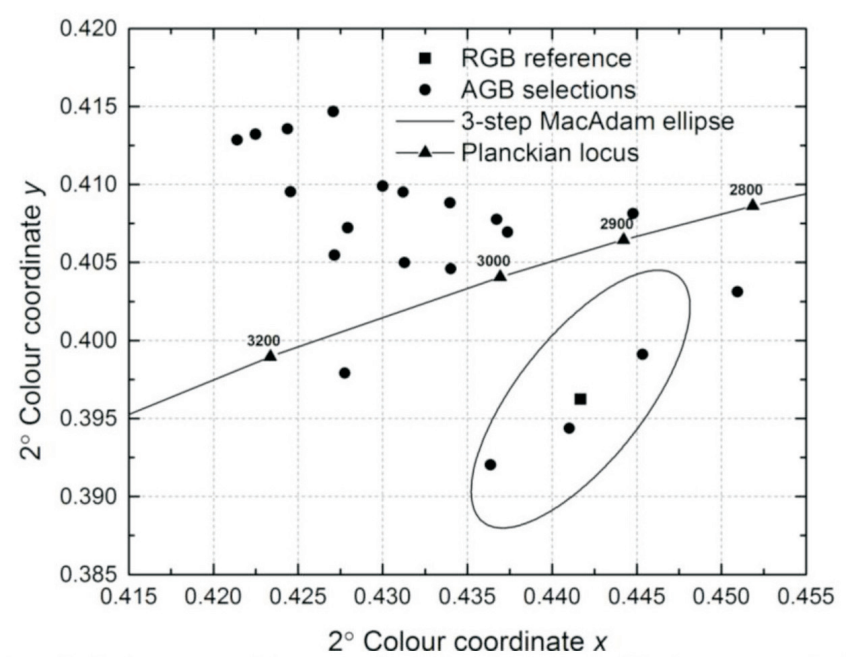

Fig. 5. Colour matching results of reference RGB (square point) and adjustable AGB (solid circles) light sources in 2-deg CIE 1931 colour space. MacAdam ellipse is drawn to illustrate the theoretical colour discrimination scale.

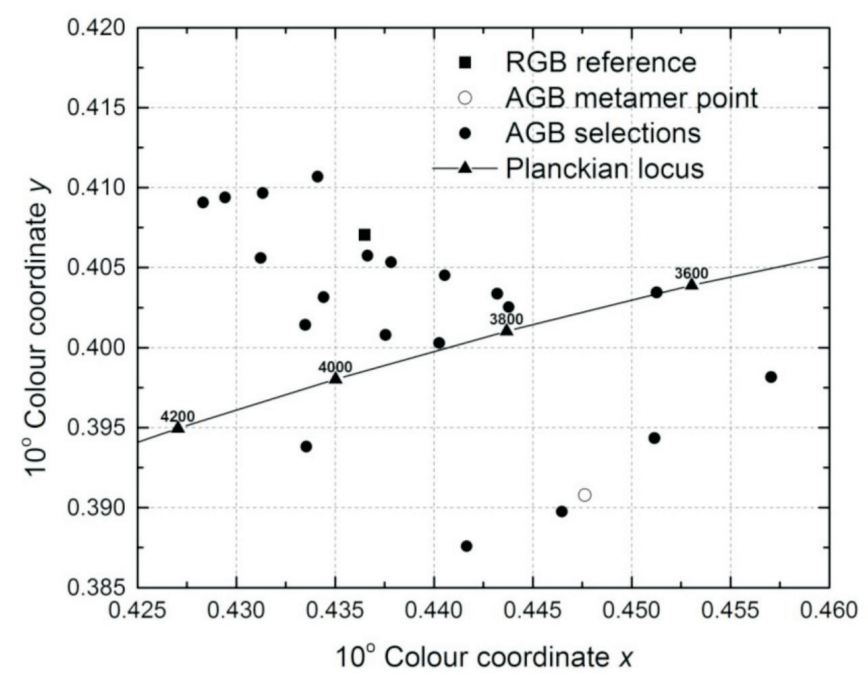

Fig. 6. Colour matching results of reference RGB (square point) and adjustable AGB (solid circles) light sources in 10-deg CIE 1964 colour space. Open circle is a theoretical coordinate of the metameric AGB source.

in 10-deg colour space than that in 2-deg colour space. The calculated average distances $\mathrm{D}_{\mathrm{uv}}$ were $0.0082 \pm 0.0027$ and $0.011 \pm 0.0025$, respectively, with a not statistically significant $p$ value of 0.096 .

For the sake of better understanding of the difference of the photometry of 2-deg and 10-deg CMFs, the LER of the most common solid-state light sources were calculated for the both CMFs and compared

$\left(\left(R_{10 / 2}=\frac{K_{10}}{K_{2}}=\int_{380}^{780} V_{10}(\lambda) S(\lambda) / \int_{380}^{780} V_{2}(\lambda) S(\lambda)\right)\right)$

(adopted from Žukauskas, 2008). Table 1 shows that for all of the evaluated sources the luminous efficacy was higher when $\lambda_{10}$ was used as the eye luminous efficacy function, and that the most significant difference was in the shortwavelength part of the spectrum. When the tetrachromatic RAGB engine of metameric light was calibrated and adjusted for 10-deg colour space, the results of $\mathrm{D}_{\mathrm{uv}}$ and other
Table 1

THE COMPARISON OF THE LUMINOUS EFFICACY OF RADIATION OF THE MOST COMMON LIGHT SOURCES UNDER 2-DEG AND 10-DEG PHOTOMETRY

\begin{tabular}{lc}
\hline \multicolumn{1}{c|}{ LED } & Ratio of $\mathrm{LER}_{10^{\circ}}$ and $\mathrm{LER}_{2}{ }^{\circ}$ \\
\hline Royal blue $(451 \mathrm{~nm})$ & 2.09 \\
Blue $(470 \mathrm{~nm})$ & 1.71 \\
Cyan $(505 \mathrm{~nm})$ & 1.20 \\
$6300 \mathrm{~K}$ & 1.12 \\
Green $(518 \mathrm{~nm})$ & 1.08 \\
$3000 \mathrm{~K}$ & 1.07 \\
$5300 \mathrm{~K}$ & 1.05 \\
$3800 \mathrm{~K}$ & 1.05 \\
Orange $(624 \mathrm{~nm})$ & 1.05 \\
Red $(638 \mathrm{~nm})$ & 1.05 \\
$2700 \mathrm{~K}$ & 1.04 \\
2000 K & 1.04 \\
Amber $(600 \mathrm{~nm})$ & 1.03 \\
pc Lime & 1.03 \\
pc Amber & 1.02
\end{tabular}

photometrical/colorimetrical parameters in 2-deg colour space appeared distorted (Table 2). Furthermore, we have to understand that most of the photometric measures like colour rendering, $\mathrm{D}_{\mathrm{uv}}$, MacAdam ellipses are calculated exclusively in 2-deg colour space and cannot be obtained in 10-deg colour space case.

\section{DISCUSSION}

Recently, the metameric illumination approach is gaining high importance for modern lighting market, where different lighting technologies and tuneable colour lights are brought together. In addition to the developed and widely recognised 2-deg CIE 1931 photometry, the more accurate 10-deg CIE 1964 was proposed for colour matching applications. On the other hand, the results of our first experiment (Fig. 4) suggests that the average observer should notice a colour difference between metamerically adjusted RGB and AGB light sources even if 10-deg photometry is used. RGB dominating metameres were perceived as too greenish, and AGB ones as too purplish. It has to be noted that observed results were obtained for two young subjects, who might be in the same group of human metameres (Sarkar et al., 2010). Furthermore, it was noticed that one dimensional adjustment along the isotemperature line in 10deg colour space was not sufficient to achieve satisfactory matching of RGB and AGB metameres. Therefore, two dimensional adjustments were introduced in the second experiment, and subjects were allowed to adjust mired CCT as well as $\mathrm{D}_{\mathrm{uv}}$. The experimental results depicted in Figures 5 and 6 show that subject selection was not homogeneous, and the assumption that subjects were from different groups of human metameres should be taken into account. Nevertheless, one can notice that quantitatively the 10-deg photometry exhibited somewhat higher accuracy and that experimental points of the AGB source were closer to that of 
COLORIMETRIC AND PHOTOMETRIC PARAMETERS OF THE METAMERIC 10-DEG $3000 \mathrm{~K}$ RAGB LIGHT ENGINE CALCULATED USING 2-DEG CIE 1931 COLOUR SPACE

\begin{tabular}{|c|c|c|c|c|c|c|c|c|c|c|c|c|c|c|c|}
\hline $\begin{array}{c}\text { Metameric light } \\
\text { source } \\
(10-\text { deg })\end{array}$ & CIE $x^{1}$ & CIE $y^{1}$ & $\mathrm{CCT}(\mathrm{K})$ & Duv & $\mathrm{dStep}^{2}$ & CIE $\mathrm{Ra}^{3}$ & CQS Qf ${ }^{4}$ & CQS Qg ${ }^{4}$ & $\mathrm{GAI}^{5}$ & $\mathrm{CFI}^{6}$ & $\mathrm{CSI}^{6}$ & $\mathrm{CDI}^{6}$ & $\mathrm{Rf}^{7}$ & $\mathrm{Rg}^{7}$ & $\begin{array}{c}\text { LER } \\
(\mathrm{lm} / \mathrm{W})\end{array}$ \\
\hline $\operatorname{AGB}(\sigma=0)$ & 0.4783 & 0.4173 & 2511 & 0.0012 & 1.4 & 70 & 75 & 84 & 39 & 31 & 0 & 55 & 75 & 93 & 348 \\
\hline $\operatorname{RAGB}(\sigma=0.22)$ & 0.4817 & 0.4131 & 2440 & -0.0004 & 0.5 & 94 & 88 & 98 & 46 & 83 & 5 & 3 & 90 & 104 & 303 \\
\hline $\operatorname{RAGB}(\sigma=0.5)$ & 0.4861 & 0.4076 & 2350 & -0.0024 & 2.9 & 61 & 65 & 111 & 51 & 19 & 70 & 1 & 70 & 113 & 257 \\
\hline $\operatorname{RGB}(\sigma=1)$ & 0.4938 & 0.3983 & 2201 & -0.0056 & 6.8 & -5 & 21 & 122 & 53 & 5 & 85 & 1 & 30 & 117 & 203 \\
\hline
\end{tabular}

\footnotetext{
1 2-deg CIE x and CIE y coordinates in CIE 1931 colour space;

2 Distance from CIE 1931 colour space Planckian locus in MacAdam ellipse steps;

${ }^{3}$ General colour rendition index CIE R $\mathrm{R}_{\mathrm{a}}$ (Commission Internationale de l'Eclairage, 1995);

${ }^{4}$ Colour fidelity scale with excluded saturation factor CQS Qf and colour gamut scale CQS Qg (Davis and Ohno, 2010);

${ }^{5}$ Gamut area index GAI (Rea and Freyssinier-Nova, 2008);

${ }^{6}$ Statistical colour rendition indices as colour fidelity index CFI, colour saturation index CSI and colour dulling index CDI (Žukauskas et al., 2009);

${ }^{7}$ Fidelity index $\mathrm{R}_{\mathrm{f}}$ and gamut index $\mathrm{R}_{\mathrm{g}}$ (David et al., 2015).
}

We emphasise the fact that most of the colour evaluation techniques are based on 2-deg CMFs.

the RGB reference source. This may suggest that the 10-deg colour space is a better choice for metameric light source description, but the wide scatter of the results and individual properties of the human vision cannot be neglected.

Mathematical comparison of the LER of the modern light sources under 2-deg and 10-deg photometry showed an increase of LER at a wider view angle (Table 1). Some results have shown that the highest luminous eye sensitivity is at 20-deg field of view ( $\mathrm{Hu}$ and Houser, 2005; Anonymous, 2014), but this field is unfortunately not employed widely. Colorimetric properties of the metameric light sources aligned at 10-deg colour space appeared distorted since the majority of parameters were measured in 2-deg colour space (Table 2) and probably could lead to a fluster in the lighting market if implemented widely.

10-deg CMFs have significant increased sensitivity in the blue region of visual spectrum but eye lenses tend to become yellowish with age (Lang, 2011) influencing the perceived gamut of colours. Since the current experiments were performed with young subjects, it does not represent information about the possible age related effects. The variety of individual vision properties and preferences makes the Standard Colorimetric Observer approach to have limited applicability, especially in professional lighting areas, and indicates the need of individually adjustable lighting.

Figure 4 shows that natural lighting condition with $\sigma=0.22$ (the closest experimental point of $\sigma=0.2$ ) cannot be distinguished from the preferential lighting with $\sigma=0.5$. In addition, Table 2 shows that transition from $\sigma=0$ to $\sigma=0.5$ isless noticeable from the transition $\sigma=0.5$ to $\sigma=1$, while comparing colour quality parameters, meaning that the colour-dulling AGB spectrum is much "closer" to natural conditions compared with the colour-saturating (RGB) spectrum. Saturating lighting $(\sigma>0.5)$ conditions with dominating red LED instead of wide-spectrum amber one was characterised by higher hue distortion and wider gamut area of illuminated objects. Probably this is a reason for the higher negative $\mathrm{D}_{\mathrm{uv}}$ values seen in Figure 4 .

\section{CONCLUSIONS}

The study of metameric light sources and their subjective evaluation showed that perceived colour is highly dependent on colour matching functions used for aligning the metameres. The most widely used CIE 1931 2-deg CMFs are not accurate enough for colour matching, while the CIE 1964 10-deg CMFs perform better. Individual vision properties of the subjects play a very important role in colour matching experiments and aggravate the employment of Standard Colorimetric Observer for precise colour applications. Implementation of individually adjustable lighting is suggested as a solution for general and professional lighting where non-compromise satisfactory is required. The metameric light sources with low red spectral component are less noticeably chromatically shifted from the natural lighting than red-rich light sources. We conclude that ideal metameric light sources should be developed and employed with caution, since observers will notice the colour difference in the narrow (2-deg) and wide field of view (> 10-deg).

\section{ACKNOWLEDGEMENTS}

The work at VU was funded from the Research Council of Lithuania by a grant (No. MIP-096/2015).

\section{REFERENCES}

Almeida, A., Santos, B., Paolo, B., Quicheron, M. (2014). Solid state lighting review: Potential and challenges in Europe. Renew. Sust. Energy Rev., 34, $30-48$. 
Barati, B., Karana, E., Sekulovski, D., Pont, S. C. (2015). Retail lighting and textiles: Designing a lighting probe set. Lighting Res. Technol., 1-22, doi: $10.1177 / 1477153515602953$.

Brown, W. R. J. (1957). Color discrimination of twelve observers. J. Opt. Soc. Amer., 47, 137-143.

Commission Internationale de l'Éclairage (CIE) (1995). Method of Measuring and Specifying Colour Rendering Properties of Light Sources. CIE Publication 13.3-1995, Central Bureau of the Commission Internationale de l'Eclairage, Vienna, Austria. 20 pp.

Commission Internationale de l'Éclairage (CIE) (2006). Fundamental Chromaticity Diagram with Physiological Axes. Part 1. CIE Publication 170-1-2006, Central Bureau of the Commission Internationale de l'Eclairage,Vienna, Austria. 44 pp.

Commission Internationale de l'Éclairage (CIE) (2007). CIE Colorimetry. Part 1: Standard Colorimetric Observers. Joint ISO/CIE standard, ISO 11664-1:2007(E)/CIE S 014-1/E:2006. Central Bureau of the Commission Internationale de l'Eclairage, Vienna, Austria. 29 pp.

Commission Internationale de l'Éclairage (CIE) (2014). Guidance towards Best Practice in Psychophysical Procedures Used when Measuring Relative Spatial Brightness. CIE Publication 212-2014, Central Bureau of the Commission Internationale de l'Eclairage, Vienna, Austria. 56 pp.

David, A., Fini, P. T., Houser, K. W., Ohno, Y., Royer, M. P., Smet, K. A. G., Wei, M., Whitehead, L. (2015). Development of the IES method for evaluating the color rendition of light sources. Opt. Express, 23 (12), $15888-15906$.

Davis, W., Ohno, Y. (2010). Color quality scale. Opt. Eng., 49 (3), 033602.

Gall, D. (2002). Circadiane Lichtgrößen und deren meßtechnische Ermittlung. Licht, 54 (11/12), 1292-1297.

Houser, K. W., Tiller, D. K. (2003). Measuring the subjective response to interior lighting: Paired comparisons and semantic differential scaling. Lighting Res. Technol., 35 (3), 183-198.

Houser, K. W., Hu, X. (2004). Visually matching daylight fluorescent lamplight with two primary sets. Color Res. Appl., 29 (6), 428-437.

Hu, X., Houser, K. W. (2005). Large-field color matching functions. Color Res. Appl., 31 (1), 18-29.
Lang, D. (2011). Energy efficient lighting for the biological clock. In: Light-Emitting Diodes: Materials, Devices, and Applications for Solid State Lighting XV, 22 January 2011, San Francisco. Proceedings of SPIE 7954, San Francisco, pp. 795402.

MacAdam, D. (1942). Visual sensitivities to color differences in daylight. $J$. Opt. Soc. Amer., 32, 247-274.

MacAdam D. (1971). Geodesic chromaticity diagram based on variances of color matching by 14 normal observers. Appl. Opt., 10 (1), 1-7.

Rea, M. S., Freyssinier-Nova, J. P. (2008). Color rendering: A tale of two metrics. Color Res. Appl. 33 (3), 192-202.

Rea, M. S., Radetsky, B. S., Bullough, J. D. (2011). Towards a model of outdoor lighting scene brightness. Lighting Res. Technol., 43(1), 7-30.

Royer, M. P., Houser, K. W. (2012). Spatial brightness perception of trichromatic stimuli. LEUKOS, 9 (2), 89-108.

Sarkar, A., Blonde, L., Callet, P., le, Autrusseau, F., Morvan, P., Stauder, J. (2010). Toward reducing observer metamerism in industrial applications: Colorimetric observer categories and observer classification. In: Eighteenth Color and Imaging Conference: Color Science and Engineering Systems, Technologies, and Applications, 8-12 November 2010, San Antonio, Texas, USA. Society for Imaging Science and Technology, San Antonio, pp. 307-313.

Tuzikas, A., Žukauskas, A., Vaicekauskas, R., Petrulis, A., Vitta, P., Shur, M. S. (2014). Artwork visualization using a solid-state lighting engine with controlled photochemical safety. Opt. Express, 22 (14), 16802-16818.

Vidovszky-Németh, A., Schanda, J. (2012). White light brightness-luminance relationship. Lighting Res. Technol., 44 (1), 55-68.

Wyszecki, G., Stiles, W. S. (1982). Color Science: Concepts and Methods, Quantitative Data and Formulae. Wiley, New York. 950 pp. (see pp. 278-394).

Wyszecki. G., Fielder, G. (1971). New Color-Matching Ellipses. J. Opt. Soc. Amer., 61, 1135-1152.

Žukauskas, A. (2008). Puslaidininkiniai šviestukai [Light-emitting diodes]. Progretus, Vilnius. 7 pp. (in Lithuanian).

Žukauskas, A., Vaicekauskas, R., Ivanauskas, F., Vaitkevičius, H., Vitta, P., Shur, M. S. (2009). Statistical approach to color quality of solid-state lamps. IEEE J. Sel. Top. Quantum Electron, 15 (6), 1753-1762.

Žukauskas, A., Vicekauskas, R., Vitta, P., Tuzikas, A., Petrulis, A., Shur, M. (2012). Color rendition engine. Opt. Express, 20 (5), 5356-5367.

Received 2 October 2016

Accepted in the final form 27 September 2017

\section{METAMĒRISKI GAISMAS AVOTI: JAUNI RISINĀJUMI FUNKCIONĀLAJĀ APGAIMOŠANĀ}

Cietvielu fizikas tehnoloǵiju attīstība regulējamo gaismas avotu jomā pēdējo gadu laikā sniedz jaunas iespējas jaunu gaismas avotu izstrādē. Kolorimetrijas standartmetodes krāsu metamēru spektru radīšanā saskaras ar problēmām, ko rada krāsu neatbilstība, ko cilvēki novēro. Izmantojot divas regulējamas tetrahromatiskas (RAGB) diožu lampas (638 nm sarkanā LED, $598 \mathrm{~nm}$ fosforizētā dzintara krāsas LED, 518 nm zaḷā LED, $451 \mathrm{~nm}$ zilā LED), tika veikts krāsu saskaṇošanas eksperiments, lai salīdzinātu metamēru krāsas 10 grādu redzeslaukā. Krāsu saskaņošana tika veikta, izmantojot 2 grādu (CIE 1931) un 10 grādu (CIE 1964) XYZ krāsu saskaņošanas funkcijas. Krāsu saskaņošanas rezultāti pierāda, ka abas standarta novērotāja krāsu saskaṇošanas funkcijas ir neprecīzas un uztvertās krāsas ievērojami atškiriras novērotāju starpā. Plašā atsevišķa novērotāja datu izkliede pierāda, ka standarta novērotāja krāsu saskaņošanas funkciju precizitāte ir ierobežota un atsevišḳos gadījumos, it īpaši tajos, kas skar profesionālu apgaismojuma ierīkošanu, jāapsver individuāli regulējamu metamērisku gaismas avotu izmantošana. 